\title{
COMBINING DifFERENT TYPES OF DATA IN STUDYING ATTITUDES TO ENGLISH AS A LINGUA FRANCA
}

\author{
MATEUSZ-MILAN STANOJEVIĆ \\ VIŠNJA KABALIN BORENIĆ ${ }^{2}$ \\ VIŠNJA JOSIPOVIĆ SMOJVER \\ Faculty of Humanities and Social Sciences, University of Zagreb ${ }^{1}$ \\ Faculty of Economics and Business, University of Zagreb ${ }^{2}$
}

\begin{abstract}
This paper deals with the attitudes of Croatian speakers to ELF, in particular to its pronunciation. Four methods were combined to reach conclusions about the status of ELF in Croatia: diary study, teacher interviews, a preliminary focus group interview and a survey. Whilst the first three methods revealed that the subjects regularly disfavour 'bad pronunciation', the survey showed that when it actually comes to talking to either native or non-native speakers, the subjects turned out to be tolerant to a slight accent. This clearly suggests a case of what is known as linguistic schizophrenia (B.B. Kachru 1977; Seidlhofer 2001). However, there are notable differences among groups of participants depending on variables such as professional profile, gender, degree of ease and success in learning pronunciation, and national pride. In any case, the combination of these methods proved to be a very good way to deal with the topic. The diary study is a valuable method to look into everyday practices and can feed nicely into survey questions. The preliminary survey highlighted the importance of different groups of participants and the need for groups of questions focusing around different factors. The preliminary focus group interview showed that it is crucial to have a single homogenous group of participants, as well as a trained facilitator. Finally, teacher interviews pointed to the possibility of similar attitudes being held by university teachers and the students they teach, which suggests that attitudes may be perpetuated. Overall, triangulation across methods and participants in the way proposed in the present paper provided a wealth of data, allowing a bottom-up view and a top-down view on the state of ELF in Croatia.
\end{abstract}

\section{Introduction}

Pronunciation of English as a Lingua Franca (ELF) first appeared as a research-based construct: on a corpus of International English conversations, Jenkins (e.g. Jenkins 2000; Jenkins 2002) postulated the existence of core features (those required for intelligibility) and non-core features (those not required for intelligibility). Intelligibility was defined in terms of non-native speaker interactions (e.g. Jenkins 1998:121). In other words, in an international communication setting, features of English pronunciation such as pre-fortis clipping and aspiration were shown to be crucial in assuring understanding, whereas features such as qualitative vowel reduction or weakening were shown not to be crucial in this respect (Jenkins 2002). At a time when the Inner Circle - Outer Circle debate has 
just ended (Kachru 1991; Kachru 1996), and the debate about the ownership of English was still in full swing (Widdowson 1994; Firth and Wagner 1997), this was bound to be a controversial issue (Jenkins 2002:101; Jenkins 2007; Jenkins 2009). What started as a fundamentally applied-linguistics concept which was meant to add "an intelligibility dimension to communicative competence" and promote "accommodation skills" (Jenkins 2002:101) proved to be highly controversial, primarily because of attitudes towards pronunciation.

It is hardly any wonder that attitudes are crucial when pronunciation is at issue. We tend to judge people by their (foreign) accent, as is well known from the famous matched guise research (Lambert 1967). As listeners we tend to prefer historically powerful over historically less powerful groups based on their pronunciation (Lindemann 2005), and we tend to prefer the in-group vs. the out-group (Dailey 2005). Our self-concept as speakers is correlated to our "objective" pronunciation performance (Chuming 2004), suggesting that affective factors underlie pronunciation performance. Different motivations might also be at play: if we learn English because we like how it sounds (results for Croatia from Mihaljević Djigunović 1991; Mihaljević Djigunović 2007), we might want to learn to sound like native speakers. Some people may want to keep their national identity, which might be reflected in their English pronunciation (Stanojević and Josipović Smojver 2011). Others might be simply influenced by their English teachers, who tend to prefer a native-like pronunciation in various ways (Sifakis and Sougari 2005; Jenkins 2006; Drljača Margić and Širola 2009; Stanojević and Josipović Smojver 2011).

Given that attitudes are crucial in ELF, a variety of issues need to be taken into consideration in order to find out about the state of ELF in a country such as Croatia. Firstly, potential differences in attitudes towards ELF among different groups of ELF speakers (e.g. according to age, gender, etc.) should be investigated. Secondly, data about actual pronunciation practices of these ELF speakers should be included to see whether (and to what extent) pronunciation practices and attitudes correspond. Thirdly, we should investigate the attitudes of English teachers towards ELF to see if they correspond to the attitudes of ELF speakers they teach. All this calls for a research model which allows top-down confirmatory investigation and bottom-up exploratory research, as well as using a variety of quantitative and qualitative methodologies to gain a balanced insight into the issues at hand (cf. e.g. Gorard 2004). In other words, we argue for a model that allows triangulation across groups of participants and methodologies (we suggest the following procedures: language diaries by ELF speakers, teacher interviews, focus group interviews, recordings of ELF speakers, and a questionnaire on attitudes).

In this paper we will provide the rationale behind these procedures and give preliminary results of combining language diaries, focus group interviews, a pilot questionnaire and teacher interviews. We will discuss what they reveal about the state of ELF in Croatia, and how they work together methodologically. The paper starts with a discussion of the ELF situation in Croatia, and the methodological rationale. The third section presents the results, followed by a discussion and conclusion. 


\section{The ELF situation in Croatia and tools for ELF studies}

Croatia has a rich tradition of research into Teaching English as a Foreign Language (TEFL), but only a few studies on the status of ELF. TEFL studies (for an overview cf. Vilke 2007) into the attitudes of secondary school learners in Croatia suggest that they are dissatisfied with teacher-centred approaches to teaching (Mihaljević Djigunović 2007:124-125). This coincides with motivation research: secondary school pupils report that they want to learn English so as to communicate with others (Mihaljević Djigunović 1991:195) in various ways, e.g. via the Internet, talking to foreigners, using email (Narančić Kovač and Cindrić 2007:71-72). This may mean that secondary school pupils are indeed willing to be independent users of ELF. The situation with university students in Croatia seems to be a bit more complex - a recent study (Stanojević and Josipović Smojver 2011) has found a clear divide between "liberal" students (ones who do not disfavour a foreign accent when speaking to others, and who do not necessarily want to work on their pronunciation), and more "traditional" ones (who do). Expectedly, the more "traditional" students are primarily English majors (cf. also Drljača Margić and Šrola 2009) whereas, for instance, business majors tend to be more liberal (Kabalin Borenić 2011). However, corresponding differences in the attitudes towards ELF were also evident among men and women, participants living in urban or rural environments and participants who assess themselves as more or less proficient pronouncers (Stanojević and Josipović Smojver 2011). Thus, other factors such as identity construction may be at play (cf. Josipović Smojver and Stanojević, in press). In order to find out what these factors might be and how this relates to actual Croglish pronunciation practices in Croatia (cf. Josipović Smojver 2010), we argue for a use of a number of different methods. We propose the use of language diaries, teacher interviews, focus group interviews, a questionnaire and (focus group) recordings. This selection of methodologies enables triangulation in the sense of a qualitative-quantitative mix, top-down and bottom-up view, as well as checking for attitudes and actual practices.

Diary studies are a good starting point, because they are exploratory in nature (Bailey 1991:61), provide access to learner introspections (cf. their use in learner strategy research; Richards 2009:157), and promote reflection (Allwright and Bailey 1991). They are a good choice at the outset of this study, because they will give us access into a range of possible attitudes towards ELF, tapping into an emic perspective that might otherwise be outside our reach as researchers. This should allow us to include the emic perspective when constructing the questionnaire about ELF attitudes.

Focus group interviews are a way to continue the emic perspective and to move away from individual attitudes, because they can tap into group meanings and norms (Bloor et al. 2001:17). They should be conducted with a relatively homogenous group of participants discussing a particular topic so as to help understand it. The discussion should be focused, and let by a skilful moderator (Krueger and Casey 2000:10). The method has been used in market research for some time (Greenbaum 1998), and has been gaining momentum in social research as well (Bloor et al. 2001). It has not been extensively used in studying attitudes of speakers of foreign languages (Ho 2006), or indeed ELF (cf. Gerritsen and Nickerson 2009:188; one exception is Grau 2009). Focus groups are well suited for ELF research, because they are a useful interpretative aid 
when survey results are available (Bloor et al. 2001:17) and a valuable triangulation tool (cf. Cohen, Manion, and Morrison 2007:377). Moreover, focus group interviews are normally recorded, which may be a source of pronunciation data. We envisage a threefold use of focus groups. Firstly, we hope to tap into group attitudes on ELF pronunciation and use, which will help us get clearer insights into the trends visible from the diary studies. Secondly, we will use focus groups to help us understand the results of the ELF questionnaire, as a way of tapping into the emic perspective. Finally, focus group recordings will be a source of objective data about English pronunciation. In order to get a relatively natural setting for speaking English in a relatively monolingual environment such as Croatia, we plan to use two facilitators who do not speak Croatian. Three practical issues that need to be taken into consideration here include sampling, training the facilitators and procedures for analyzing the recorded pronunciations, which we cannot go into detail here.

The interview is a technique which allows a more in-depth look into individual factors that may come up (as opposed to focus group interviews which investigate group attitudes). It has been used time and again in ELF research with ELF speakers (Erling and Bartlett 2006) and teachers (Jenkins 2005; Jenkins 2007; Jenkins 2009; Trent and Lim 2010). We propose non-structured interviews with teachers of English at universities across Croatia. Some recent survey-based studies in Croatia have found that future teachers of English are not really open to teaching ELF (Drljača Margić and Širola 2009; Josipović Smojver and Stanojević, in press), which is in line with Jenkins' results saying that teachers of English are ambivalent towards ELF (Jenkins 2007). By talking to Croatian teachers of English in academic settings, we hope to gain a deeper insight into these issues and possible reasons behind them. Importantly, however, we will be looking whether teacher attitudes are reflected in the attitudes of ELF speakers.

Finally, we envisage the use of a questionnaire on the attitudes towards ELF, which will give us quantitative results. There are a number of general and practical issues involved in questionnaire use in education research - from the way in which a questionnaire is constructed to its administration (cf. e.g. Cohen, Manion, and Morrison 2007, 317-348; Dörnyei 2010). In this study, we have decided on using a pilot with a number of closed questions regarding the attitudes to ELF on three groups of participants. The results of the pilot feed into the focus group interviews (where we ask for comments on some of its results), as well as the construction of the final questionnaire (which will again be piloted).

Overall, we believe that this makes for a good mix of methodologies, giving a reasonably comprehensive view of the state of ELF in Croatia. It provides methodological triangulation because: (1) it combines attitude research with actual recordings of ELF; (2) it allows exploration as well as confirmation; (3) it brings together quantitative as well as qualitative data analysis; and (4) it looks into the attitudes of teachers as one of the possible "takes" on what is going on with ELF speakers. In the next section we will present and discuss some of our results in the application of this research architecture. 


\section{Results}

\section{Diary study}

The purpose of the diary study was to explore the attitudes of individual ELF speakers towards their English use in everyday situations. The participants were asked to keep a diary for seven days and reflect on the following issues: how they and their conversational partners used English that day, which aspect of their English use might have stood out, why (or why not), and how they felt when using English. The participants were volunteers, who had attended a class on Business English taught by the second author. They were given a book for participating in the study. We sent out 15 invitations, and got back diaries from four participants (three male and one female, all in their early or mid twenties). The low return rate was expected - although the participants were alerted to the possible benefits of using a diary study (e.g. better awareness of their use of English), they were no longer attending classes, and their internal (and external) motivation seems not to have been sufficient. We performed a qualitative analysis of the diary entries.

The results show that English was used as a matter of course in a variety of everyday situations with native and non-native speakers of English. The results were particularly enlightening with regard to: the use of English as a code-switching practice, the use of English with other native and non-native speakers, and their attitudes towards English pronunciation.

The participants used English as part of their everyday Internet conversations (e.g. chat), mostly by code switching from Croatian to English (in the words of one of the participants: "I would use a phrase such as Hello, What's up or Bye from time to time"). All of the participants consider this type of code-switching an everyday practice, which they believe everyone does at their age ("this is an everyday choice - I think in a mixture of English and Croatian, and I frequently think of an English expression first, plus I am certain that my conversational partner will understand me"). This is not strictly speaking an ELF use, but English code switching was noted in different countries, and in a variety or registers (McClure 1998). When it comes to computer-mediated communication, it might be an identity-building practice which affirms group identity and communality (cf. e.g. Androutsopoulos 2004; Leppänen 2007). Perhaps this is reflected in responses such as "I believe that most young people use English when communicating via chat" or "it has become normal to use [English], especially among young people", where participants refer to themselves as "young people" which might be the identity they want to build.

The reported ELF use ranges from online chat with other non-native and native speakers to speaking English with native speakers face-to-face and to formal writing in English. When faced with an "unplanned" face-to-face conversation with a non-native speaker, one of the participants reports that she felt "surprised and taken aback, but later [her] speech became more fluent". The participants who used ELF in online chats and forums do not report such a feeling: "I used English as I do it every day, there was nothing special about it" or "My choice of English was a matter of course, because for many people on the forum English is their native tongue". A reason why they do not report surprise may be due to increased control (you can choose whether you want to 
enter a chat or a forum and when) and familiarity with their conversational partners (they referred to them as "friends" and "acquaintances"), making the situation less stressful.

The participants do not seem to give much thought to their own English pronunciation. Three participants constantly report being particularly aware of "grammatical accuracy", "syntax" and "spelling, for instance not being careful with capitalizing when using chat", and a single participant mentions that he paid attention to his pronunciation on two occasions. This is not surprising, keeping in mind that most of their ELF use is written rather than spoken. Still, when reporting on the speech of others, all four participants mention pronunciation. For instance, when talking to a tourist faceto-face, one participant noticed that "he pronounced things wrong, because English wasn't his mother tongue, which made him difficult to understand". When pronunciation is not "incorrect", it remains unnoticed: "I do not pay attention to the accent and grammatical accuracy of my acquaintances, because all of them speak English well, the communication flows without problems, and they pronounce English well". As for particular accents, only British and American English are mentioned, American English being the norm: "British English, ... is not so usual for me; I usually listen to American English" or "I like the sound of American English much better than British English".

The results show that English is used in code-switching and in talking to native and non-native speakers. The participants notice the pronunciation of their conversational partners when they pose communication problems or are different from what they are used to. Methodologically, the data suggest that the final questionnaire should include questions concerning the situations when English is used, and particular English accents. Still, a larger sample of diaries from a variety of participants would be instrumental to generalize the results.

\section{Preliminary survey}

The preliminary survey was conducted on a sample of 2498 participants from throughout Croatia, most of who were university students $(58.6 \%)$, and the remaining were secondary school pupils $(25.5 \%)$ and employees in a large international company $(15.9 \%)$. Most of the participants were female (67.9. They were given an anonymous questionnaire in Croatian, which contained 31 items (16 on a 5-point Likert scale and the remaining offering a selection of several options). Four questions dealt with attitudes to the regional pronunciation of Croatian. Seventeen questions dealt with attitudes to English (beliefs about the importance of fluency, grammar and pronunciation, attitudes towards one's own pronunciation of English when speaking to native and non-native speakers, attitudes towards learning English pronunciation, beliefs about the ease of understanding non-native speakers, and attitudes towards (non-)native teachers of English). The remaining questions dealt with participant data (for details on the questionnaire cf. Stanojević and Josipović Smojver 2011 and Josipović Smojver and Stanojević, in press). The aim of the questionnaire was to explore whether there were any links between the participants' characteristics (e.g. pupil vs. student vs. employee; liberal vs. traditional attitudes towards Croatian; gender; and self-assessed proficiency) and the way one perceives one's own accent, the accent of one's conversational partners and teaching models.

The results show that most participants find pronunciation important $(89 \%$ agree or strongly agree that "correct pronunciation" is important), and $67 \%$ of participants agree 
that perfecting English pronunciation so as to pass for a native speaker is a worthwhile endeavour, regardless of the time and effort it would take. Still, most believe that some foreign accent is okay when talking to native or non-native speakers of English: most participants would not mind having a strong or slight accent when talking to native speakers $(76.1 \%)$ or non-native speakers $(82.3 \%)$. Native speakers are not preferred as teachers of English pronunciation $(M=3.24, S D=1.23)$, and the pronunciation of nonnative conversational partners is not preferred over native conversational partners $(M=$ 2.97, $S D=1.32$ ).

As expected, ANOVA showed that there were significant differences between secondary school pupils, university students and company employees on all six questions: the attitude towards perfecting their pronunciation so as to pass for a native speaker $(F(2,2480)=31.94, p<.001)$, the importance of pronunciation when speaking $(F(2,2353)=8.76, p<.001)$, the acceptability of foreign accent when talking to native speakers $(F(2,2476)=4.67, p=.009)$ and non-native speakers $(F(2,2470)=7.57, p<$ $.001)$, the belief that native speakers are better teachers of pronunciation than non-native speakers $(F(2,2444)=15.48, p<.001)$, and the preference for non-native speakers as conversational partners $(F(2,2485)=8.81, p<.001)$. Generally, company employees tend to be on one end of the scale and pupils/students on the other. Scheffe's post-hoc test showed that employees scored significantly lower than pupils and students on wanting to perfect their pronunciation, scored significantly higher on wanting native speaker teachers, scored significantly higher on disfavouring a foreign accent with nonnative speakers, and scored significantly higher on preference for non-native speakers as conversational partners. Scheffe showed no differences in disfavouring a foreign accent when talking to native speakers (all groups score rather high on disfavouring a foreign accent). Although all participants agree that correct pronunciation is important, Scheffe's post hoc test showed that secondary school pupils scored significantly lower than university students (with employees in the middle).

Participants who strongly disagreed that ideal Croatian pronunciation should be regionally unmarked (i.e. they have a "liberal" attitude towards Croatian pronunciation), generally had a more liberal attitude towards English pronunciation. ANOVA showed that there were significant differences between groups on four of the six questions: the importance of pronunciation when speaking English $(F(4,2344)=8.35, p<.001)$, the acceptability of foreign accent when talking to native $(F(4,2468)=15.08, p<.001)$ and non-native speakers $(F(4,2461)=13.99, p<.001)$, and the attitude towards perfecting their pronunciation so as to pass for a native speaker $(F(4,2470)=2.73, p=.028)$. Scheffe's post-hoc test showed that participants with a liberal attitude towards Croatian scored significantly lower than all or most other participants on the importance of English pronunciation and disfavouring one's foreign accent when talking to native or non-native speakers of English. There were no significant differences between groups with regard to preferring native speakers as pronunciation teachers, and preferring nonnative conversational partners.

Gender differences were found on five of the six questions. Women scored significantly higher than men on the importance of pronunciation when speaking English $(t(2345)=4.06, p<.001)$, the acceptability of foreign accent when talking to native $(t(2469)=3.53, p<.001)$ and non-native speakers $(t(2462)=2.71, p=.007)$, the attitude towards perfecting their pronunciation so as to pass for a native speaker $(t(2472)=8.71$, 
$p<.001)$, and preferring non-native conversational partners $(t(2475)=3.70, p<.001)$. There were no significant differences between men and women on preferring native teachers.

Finally, ANOVA showed that there were significant differences between participants on all six questions with regard to how they assessed their own pronunciation: the importance of pronunciation when speaking English $(F(4,2337)=44.09, p<.001)$, the acceptability of foreign accent when talking to native $(F(4,2460)=39.48, p<.001)$ and non-native speakers $(F(4,2454)=28.09, p<.001)$, the attitude towards perfecting their pronunciation so as to pass for a native speaker $(F(4,2464)=5.12 ; p<.001)$, the belief that native speakers are better teachers of pronunciation than non-native speakers $(F(4,2429)=8.23, p<.001)$, and preferring non-native over native conversational partners $(F(4,2468)=49.66, p<.001)$. Scheffe's post-hoc test showed that speakers who rate their pronunciation as poor score significantly lower than all other groups on the importance of a correct pronunciation in English, wanting to perfect their pronunciation, disfavouring a foreign accent when talking to native and non-native speakers, and on wanting a native speaker to teach them pronunciation. Scheffe showed that participants who rated their pronunciation as excellent or very good scored significantly lower on preferring native speakers as conversational partners. Scheffe showed no differences between groups on the attitude towards perfecting one's pronunciation so as to pass for a native speaker.

These results suggest that all of the explored parameters - participant profile, attitudes towards Croatian, gender, and self-assessed proficiency may influence the way in which one perceives the importance of English pronunciation, the acceptability of foreign accent when talking to native and non-native speakers and the attitude towards perfecting one's pronunciation so as to pass for a native speaker. Significant differences in the attitudes towards native vs. non-native teachers appeared only when learner status was at issue (i.e. among students/pupils vs. employees, and different groups according to self-assessed pronunciation proficiency), but not among groups according to gender or the attitude towards Croatian. Significant differences in the attitudes towards non-native conversational partners were present only between participants who had different attitudes towards English, but not between subjects who had different attitudes to Croatian. This suggests that the attitudes towards ELF may include several components (e.g. one's own actual pronunciation practice vs. teaching and learning pronunciation), and may be related to two different sources of more or less liberal attitudes - those referring to one's own status in the learner-speaker continuum, and those referring to other sociophonetic factors (e.g. gender, attitudes towards one's native language).

\section{Preliminary results of teacher interviews and focus group interviews}

In addition to the two studies reported on above, we conducted three interviews with university lecturers of English, and three focus group interviews with business majors attending the Faculty of Economics and Business. They were used to obtain preliminary results and get the feel for the methods at hand.

Three semi-structured interviews were conducted by the third author with university lecturers of English as a Foreign Language, one teaching English teacher majors, one engineering majors, and one business majors. It was a semi-structured interview, dealing with the teachers' beliefs about teaching pronunciation, appropriate models, ELF 
pronunciation, and with how they think their students regard pronunciation. The aim of the interview was to see to what extent the attitudes of actual English teachers coincided with the results of the preliminary questionnaire.

There were differences between the three participants depending on where they teach. The participant teaching engineering majors believes that, when international communication is at issue, pronunciation is a "means to an end", which should be taught only when serious misunderstanding might occur. The lecturer teaching business majors believes that pronunciation is important for her students, in the sense that when they communicate with others they might be judged by their pronunciation. The lecturer teaching future teachers of English believes that pronunciation is paramount. All three participants believe that their students hold the same views. When appropriate teaching models are discussed, native models come to the fore, and all three participants explicitly mention British and American English. As one of the participants says, British English has a special status in Croatia, "because it used to be preferred in my education, and my entire teaching career seems to have been revolving around it, but I am well aware of American English as well". All three agree that American English is the model of choice among their students, and that students in general (at least on the declaratory level) prefer native models. Finally, all three participants are keenly aware of the ELF pronunciation as being present to various extents in international communication. They accept it up to a point: when communication needs to be achieved, ELF might be an okay choice, but certainly not "when future teachers of English are concerned" (who should strive towards a native model). All three participants believe that ELF should certainly not be a teaching model. One of them fears that "language might disintegrate" because of this.

The results were somewhat expected - lecturers teaching students of different profiles seem to be in touch with their students' attitudes which followed from the questionnaire (e.g. English majors going for native-like pronunciation, or engineering majors going for understandability). Of course, the issue is whether these attitudes might be perpetuated by the teachers themselves (cf. Stanojević and Josipović Smojver 2011). On the methodological level, it is clear that valuable data can be obtained by using this method, and that, given a larger sample, this data may supplement the data obtained from the students.

Three focus group interviews were conducted with a group of business majors, as a part of another unrelated study by the second author. The participants were asked to comment on two findings: that most business majors prefer to talk to native speakers and that they want to improve their pronunciation so as to pass for a native speaker. The results show that the native speaker is seen as an authority figure by the members of the focus groups, in the words of one participant: "I will learn more from a native speaker, the non-native speaker's mistakes might rub off on me". The authority of native speakers (American English is preferred by the students) is no doubt connected with the prestige of native accents: "you might be ashamed of your bad accent, you might be the laughing stock of others [if you speak] Russian English or French English". Or: "People perceive your speech as worse if you have a foreign accent, regardless of correctness or fluency". Thus, imitating a native variety might be a point of pride ("It is a challenge"; "I feel good when I can do it"). Finally, the reasons behind going for native accents might also 
be issues of understanding: half of the focus group participants believe that it is easier to understand native speakers.

As we hoped, the results of the focus group interviews provided a detailed account of the reasons behind the answers of the business majors on the questionnaire, and highlighted the need for multiple focus groups for different groups of participants. On a practical level, this first attempt at using a focus group made it clear that better results might be expected if training is provided for the facilitator, and if the focus group is conducted in a more informal atmosphere, which is in accordance with the practical suggestions from the literature (Krueger and Casey 2001). Moreover, it illustrated the possible difficulty of creating a relaxed atmosphere vs. the need to make recordings that are sufficiently high quality to be phonetically analyzed. These issues still remain to be resolved.

\section{Discussion, conclusion and outlook}

The results concerning the state of ELF in Croatia suggest several things. Firstly, there is a clear case of linguistic schizophrenia (B. B. Kachru 1977; Seidlhofer 2001): one should take time to study "proper" (i.e. native-like) pronunciation (cf. teacher interviews, the survey), and a "bad pronunciation" is always noticeable (diaries, teacher interviews, the survey, the focus group). Still, when it comes to talking to native or non-native speakers, slight accent is okay (the survey). Attaining a native-like accent may be a good reason for particular pride (the focus group). Overall, there are clear differences in the attitudes towards pronunciation between different groups of participants: pupils, students and employees, men and women, better and worse pronouncers and participants with different attitudes towards Croatian (the survey). We need to get different groups of participants to do diaries, take part in focus groups and teacher interviews, which would shed light on these differences. Our focus on business majors showed that they use English as part of their everyday life, that they notice the pronunciation of others (diaries), and that native varieties for them are a source of prestige (the focus group). In a study which looked into the differences among university students with different majors in Croatia (Stanojević and Josipović Smojver 2011), business majors tended to be in the middle of the scale (in between, e.g. students majoring in engineering and English). In the light of this finding, we expect different results from diary studies and focus groups with different participants.

It was rewarding to see that the various methods work well together, and that the proposed triangulation may be a good way to gather extensive data, which will (eventually) correspond to each other in different ways. We learned that the diary study is a valuable method to look into the everyday practices, and that it may feed into questions in the questionnaire concerning the everyday practices (such as internet use, and communication in English). The preliminary survey highlighted the importance of different groups of participants, and constructing groups of questions focusing around different factors. The preliminary focus group interview showed that it is crucial to have a single homogeneous group of participants, as well as a trained facilitator. We must consider and try out the idea of recording the focus group to obtain actual pronunciation data - and confirm the discrepancy between the actual pronunciation and attitudes. 
Teacher interviews pointed to the possibility of similar attitudes being held by university teachers and the students they teach, which may indicate that attitudes are perpetuated. Overall, triangulation across methods and participants in the way proposed here provided a wealth of data, allowing a bottom-up view and a top-down view on the state of ELF in Croatia. What remains to be seen is how these data on attitudes towards ELF will relate to actual pronunciation practices.

\section{References}

Allwright, Dick, and Kathleen M. Bailey. 1991. Focus on the Language Classroom: An Introduction to Classroom Research for Language Teachers. Cambridge University Press.

Androutsopoulos, Jannis. 2004. Non-native English and Sub-cultural Identities in Media Discourse. In Den Fleirspråklege Utfordringa, ed. Helge Sandøy, Endre Brunstad, and Jon Erik Hagen, 83-98. Oslo: Novus.

Bailey, Kathleen M. 1991. Diary Studies of Classroom Language Learning: The Doubting Game and the Believing Game. In Language Acquisition and the Second/Foreign Language Classroom, ed. Eugenius Sadtono, 60-102. Singapore: SEAMEO Regional Language Center.

Bloor, Michael, Jane Frankland, Michelle Thomas, and Kate Robson. 2001. Focus Groups in Social Research. London, Thousand Oaks, New Delhi: Sage Publications.

Chuming, Wang. 2004. A Study on the Relationship between English Pronunciation Self-concept and Actual Pronunciation. Foreign Language World (5).

Cohen, Louis, Lawrence Manion, and Keith Morrison. 2007. Research Methods in Education. London; New York: Routledge.

Dailey, R. 2005. Language Attitudes in an Anglo-Hispanic Context: The Role of the Linguistic Landscape. Language \& Communication 25 (1): 27-38. doi:10.1016/j.langcom.2004.04.004.

Dörnyei, Zöltan. 2010. Questionnaires in Second Language Research: Construction, Administration, and Processing. 2nd ed. New York: Routledge.

Drljača Margić, Branka, and Dorjana Širola. 2009. (Teaching) English as an International Language and Native Speaker Norms: Attitudes of Croatian MA and BA Students of English. English as an International Language Journal 5: 129-136.

Erling, Elizabeth J, and Tom Bartlett. 2006. Making English Their Own: The Use of ELF Among Students of English at the Free University of Berlin. Nordic Journal of English Studies 5 (2): 9-40.

Firth, Alan, and Johannes Wagner. 1997. On Discourse, Communication, and (Some) Fundamental Concepts in SLA Research. The Modern Language Journal 81 (3): 285-300.

Gerritsen, Marinel, and Catherine Nickerson. 2009. BELF: Business English as a Lingua Franca. In The Handbook of Business Discourse, ed. Francesca Bargiela-Chiappini, 180-192. Edinburgh: Edinburgh University Press.

Gorard, Stephen. 2004. Combining Methods in Educational and Social Research. Maidenhead: Open University Press. 
Grau, Maike. 2009. Worlds Apart? English in German Youth Cultures and in Educational Settings. World Englishes 28 (2): 160-174.

Greenbaum, Thomas L. 1998. The Handbook for Focus Group Research. Thousand Oaks, London, New Delhi: Sage Publications.

Ho, Debbie. 2006. The Focus Group Interview: Rising to the Challenge in Qualitative Research Methodology. Australian Review of Applied Linguistics 29 (1). http://www.nla.gov.au/openpublish/index.php/aral/article/view/1914. Accessed on Feb 23, 2012.

Jenkins, Jennifer. 1998. Which Pronunciation Norms and Models for English as an International Language? ELT Journal 52 (2): 119-126.

Jenkins, Jennifer. 2000. The Phonology of English as an International Language: New Models, New Norms, New Goals. Oxford: Oxford University Press.

Jenkins, Jennifer. 2002. A Sociolinguistically Based, Empirically Researched Pronunciation Syllabus for English as an International Language. Applied Linguistics 23 (1): 83-103.

Jenkins, Jennifer. 2005. Implementing an International Approach to English Pronunciation: The Role of Teacher Attitudes and Identity. TESOL Quarterly 39 (3): 535-543.

Jenkins, Jennifer. 2006. Current Perspectives on Teaching World Englishes and English as a Lingua Franca. TESOL Quarterly 40 (1): 157-181.

Jenkins, Jennifer. 2007. English as a Lingua Franca: Attitude and Identity. Oxford Applied Linguistics. Oxford University Press.

Jenkins, Jennifer. 2009. English as a Lingua Franca: Interpretations and Attitudes. World Englishes 28 (2): 200-207.

Josipović Smojver, Višnja. 2010. Foreign Accent and Levels of Analysis: Interference between English and Croatian. In Issues in Accents of English 2: Variability and Norm, ed. Ewa Waniek-Klimczak, 23-35. Newcastle: Cambridge Scholars Publishing.

Josipović Smojver, Višnja, and Mateusz-Milan Stanojević (in press) Stratification of English as a Lingua Franca: Identity Constructions of Learners and Speakers. In Teaching and Researching English Accents in Native and Non-native Speakers, ed. Ewa Waniek-Klimczak and Linda Shockey. Springer.

Kabalin Borenić, Višnja. 2011. Attitudes to English and EFL Motivation in Croatian University Students of Business - Results of a Pilot Research Study. In UPRT 2010 : Empirical Studies in English Applied Linguistics, ed. Magdolna Lehmann, Réka Lugossy, and József Horváth, 135-151. Pécs: Lingua Franca Csoport.

Kachru, Braj B. 1977. Linguistic Schizophrenia and Language Census: A Note on the Indian Situation. Linguistics 15 (186): 17-32.

Kachru, Yamuna. 1991. Speech Acts in World Englishes: Toward a Framework for Research. World Englishes 10 (3): 299-306.

Kachru, Yamuna. 1996. Kachru Revisits Contrasts. English Today 12 (1): 41-44.

Krueger, Richard A., and Mary Anne Casey. 2000. Focus Groups: a Practical Guide for Applied Research. Thousand Oaks, London, New Delhi: Sage Publications. 
Krueger, Richard A., and Mary Anne Casey. 2001. Designing and Conducting Focus Group Interviews. In Social Analysis: Selected Tools and Techniques, ed. Richard A. Krueger, Mary Anne Casey, Jonathan Donner, Stuart Kirsch, and Jonathan N. Maack, 4-23. Social Development Papers 36. Washington: Social Development Deparment. $\quad \mathrm{http}: / /$ siteresources.worldbank.org/SOCIALANALYSIS/11048901120158652972/20566697/SDP-36.pdf\#page=10. Accessed on Feb 23, 2012.

Lambert, Wallace E. 1967. A Social Psychology of Bilingualism. Journal of Social Issues 23 (2): 91-109.

Leppänen, Sirpa. 2007. Youth Language in Media Contexts: Insights into the Functions of English in Finland. World Englishes 26 (2): 149-169.

Lindemann, Stephanie. 2005. Who Speaks 'broken English'? US Undergraduates' Perceptions of Non-native English. International Journal of Applied Linguistics 15 (2): 187-212.

McClure, Erica. 1998. The Relationship between Form and Function in Written National Language - English Codeswitching: Evidence from Mexico, Spain and Bulgaria. In Codeswitching Worldwide, ed. Rodolfo Jacobson, 125-150. Berlin, New York: Mouton de Gruyter.

Mihaljević Djigunović, Jelena. 1991. Nastava engleskog jezika i motivacija za učenje. Unpublished Ph. D. dissertation, Zagreb: University of Zagreb.

Mihaljević Djigunović, Jelena. 2007. Croatian EFL Learners' Affective Profile, Aspirations and Attitudes to English Classes. Metodika 8 (14): 115-126.

Narančić Kovač, Smiljana, and Ivana Cindrić. 2007. English Language Needs of Croatian Students. Metodika 8 (14): 68-83.

Richards, Keith. 2009. Trends in Qualitative Research in Language Teaching Since 2000. Language Teaching 42 (02): 147-180.

Seidlhofer, Barbara. 2001. Closing a Conceptual Gap: The Case for a Description of English as a Lingua Franca. International Journal of Applied Linguistics 11 (2): 133158.

Sifakis, Nicos C., and Areti-Maria Sougari. 2005. Pronunciation Issues and EIL Pedagogy in the Periphery: A Survey of Greek State School Teachers' Beliefs. TESOL Quarterly 39 (3): 467-488.

Stanojević, Mateusz-Milan, and Višnja Josipović Smojver. 2011. Euro-English and Croatian National Identity: Are Croatian University Students Ready for English as a Lingua Franca? Suvremena lingvistika 37 (71): 105-130.

Trent, John, and Jenny Lim. 2010. Teacher Identity Construction in School-university Partnerships: Discourse and Practice. Teaching and Teacher Education 26 (8): 1609 1618.

Vilke, Mirjana. 2007. English in Croatia - a Glimpse into Past, Present and Future. Metodika 8 (14): 17-24.

Widdowson, Henry. 1994. The Ownership of English. TESOL Quarterly 28 (2): 377389. 